\title{
A new tactic for Triatoma infestans control: fabrics impregnated with beta-cypermethrin
}

\author{
Edgardo Wood, ${ }^{1}$ Susana A. de Licastro, ${ }^{1}$ Norma Casabé, ${ }^{1}$ \\ María Inés Picollo, ${ }^{1}$ Raúl Alzogaray, ${ }^{1}$ and Eduardo Nicolás Zerba ${ }^{1}$
}

\begin{abstract}
Triatoma infestans is the most important vector of Chagas' disease in Argentina. Experiences from Argentine national campaigns have shown indoor spraying to control triatomine bugs is both expensive and difficult. An alternative control method may be the use of pyrethroidimpregnated fabrics (PIFs), which could be both a practical and cheap complement to conventional control measures. In this study, a formulation of emulsifiable concentrate of $\beta$-cypermethrin [ $\alpha$-cyano-3-phenoxybenzyl-3-(2,2-dichlorovinyl)-2,2-dimethylcyclopropanecarboxilate] pyrethroid was used to impregnate different fabrics. The fabrics were then tested for their efficacy and persistence in killing Triatoma infestans. Insects attempting to penetrate or grasp the fabric in search of blood meals were poisoned by the exposure to the absorbed pyrethroid.

Laboratory bioassays showed that the insecticidal effect of the PIFs with a dosage of $0.2 \mathrm{~g} / \mathrm{m}^{2}$ lasted longer on wool than on cotton or rayon. Eight months after impregnation, a residual efficacy of $100 \%$ was found for wool, $80 \%$ for rayon-cotton fabrics, and $50 \%$ for rayonpolyester fabrics. In addition, $\beta$-cypermethrin-impregnated fabrics showed a better repellency effect than did fabrics impregnated with either deltamethrin or cypermethrin.

For field trials, fabrics were impregnated either in the laboratory or "in situ" at a dosage of $1 \mathrm{~g} \beta$-cypermethrin $/ \mathrm{m}^{2}$ and then dried. The PIFs were placed inside homes, either under the roof or under the bed mattress. The field trials showed the PIF approach to be very effective in keeping dwellings free of triatomine bugs for at least one year and found a high degree of acceptability among the houses' residents.
\end{abstract}

Nets are being used worldwide to protect people from biting insects (1). Impregnation of bednets with pyrethroids represents the most important advance in malaria vector control since the invention of residual house spraying $(2,3)$.

Different formulations of permethrin and deltamethrin, as well as different netting, have been used to establish

\footnotetext{
Centro de Investigaciones de Plagas e Insecticidas (CITEFA-CONICET), Buenos Aires, Argentina. Send correspondence to: Eduardo Nicolás Zerba, Centro de Investigaciones de Plagas e Insecticidas (CITEFA-CONICET), Zufriategui 4380 (1603), Buenos Aires, Argentina. Fax: 5411-4709-3210. E-mail: info@cipein.com.ar
}

which combinations of pyrethroid and netting are the most effective in mosquito control (4-6). Field trials have been performed in Africa, Asia, and such Western Hemisphere countries as Mexico, Venezuela, Guyana, and Suriname (7). Since 1982, the World Health Organization has recommended extensive field trials with pyrethroidimpregnated nets $(8,9)$.

According to MacCormack (10), experiences in China and India showed that impregnating nets was acceptable and people were willing to use them. The primary health care system in many countries should be well suited to the organization of such operations.
In Argentina, Triatoma infestans Klug (Hemiptera: Reduviidae) is the most important vector of Chagas' disease (11). Experiences from the national campaigns in that country have shown that indoor spraying is not only expensive but also sometimes difficult due to organizational problems and many residents' lack of acceptance of the practice. Houses are generally far from one another, and sometimes there are no roads for the vehicles from the spraying task forces to reach the dwellings. Inhabitants dislike conventional chemical vector control because they have to take all of their personal belongings out of their houses 
during the spraying. Therefore, alternative methods of control are necessary, especially those that can be implemented through community participation $(12,13)$.

Pyrethroid-impregnated fabrics (PIFs) are a completely new application of pyrethroids for Chagas' disease vector control and provide a practical and cheap complement to conventional control measures.

$\beta$-cypermethrin has been evaluated in our laboratory and compared with deltamethrin and other pyrethroids being used in the Argentine national campaigns for Chagas' disease vector control (14). Comparing the 50\%mortality lethal dose $\left(\mathrm{LD}_{50}\right)$ amounts, $\beta$-cypermethrin is three times more effective than deltamethrin for nymphs I and twice as effective for nymphs $\mathrm{V}$, but slightly less effective for adult insects of Triatoma infestans (15). $\beta$ cypermethrin could thus be a promising alternative for Chagas' disease vector control.

In this research, various kinds of fabrics, including wool, cotton, polyester, and rayon, were assayed to find the best combination of fabric support and $\beta$-cypermethrin for satisfactory triatomicidal activity. The research demonstrated the efficacy of PIFs in terms of mortality and repellency, in both the laboratory and the field.

\section{MATERIALS AND METHODS}

\section{Fabrics, chemicals, and biological material}

Eight different fabrics were assayed. The fabrics were: $58 \%$ cotton and $42 \%$ polyester, $100 \%$ pure wool, $43 \%$ rayon and $57 \%$ cotton, $51.2 \%$ rayon and $48.8 \%$ polyester, $100 \%$ cotton, $100 \%$ cellulose acetate ("taffeta"), $100 \%$ polyester (a wide-mesh fabric called "tulle"), and $100 \%$ nylon ("voile").

Three chemicals were used in this research. One was deltamethrin, from Agrevo (Argentina); as a 5\% emulsifiable concentrate (EC) it is called DECIS. The second chemical was cypermethrin, from Chemotécnica S.A. (Argentina), as a $25 \% \mathrm{EC}$. The third chemi- cal, $\beta$-cypermethrin, is a mixture of isomers of cypermethrin ( $\alpha$-cyano-3-phenoxybenzyl-3-(2,2-dichlorovinyl)-2,2 dimethylcyclopropanecarboxilate) containing 38\% 1Rcis $\mathrm{S}+1 \mathrm{Scis} \mathrm{R}$ and $57.5 \% 1$ Rtrans S + 1Strans R. As a 5\% EC formulation, it is called Chinmix (Chemotécnica S.A., Argentina). $\beta$ cypermethrin provides a wide efficacy spectrum but with a relatively low environmental risk (16). A literature review shows that $\beta$-cypermethrin is slightly more toxic than pyrethrin I and belongs to the cost-effective group of pyrethroids (17). It is not hazardous to humans at the low recommended dosages (18).

The biological material consisted of a susceptible strain of Triatoma infestans that was reared from a colony in our laboratory and that was maintained at $28-30{ }^{\circ} \mathrm{C}$ and $50-60 \% \mathrm{RH}$ (19). The insects selected for toxicological tests were first-instar nymphs (3-5 days old) that had been starved since eclosion (20).

\section{Laboratory trials}

A number of laboratory trials were done to characterize the commercial fabrics and to standardize them before the field trials. To assess the water absorption of the fabrics, fabric rectangles of $12.5 \times 25 \mathrm{~cm}$ were placed in a graduated cylinder containing $50 \mathrm{~mL}$ of water at $25^{\circ} \mathrm{C}$. After $30 \mathrm{~min}$, the fabric was removed, the excess water allowed to drip off for $5 \mathrm{~min}$, and the amount of water the fabric absorbed was measured. Absorbency was defined as the amount of water absorbed per square meter during $30 \mathrm{~min}$ at $25^{\circ} \mathrm{C}$.

The analysis of the chemical composition of the fabrics was done by the Textile Investigation Center (INTI, Buenos Aires, Argentina), using established techniques (21).

A Nikon (Japan) model SKe optical microscope was used to examine pieces of fabric, and the number of fibers per $\mathrm{cm}^{2}$ were counted using an ocular micrometer (40x).

For impregnation testing, rectangles of fabrics $12.5 \times 25 \mathrm{~cm}$ were immersed for $1 \mathrm{~h}$ at a concentration of $0.2 \mathrm{~g} / \mathrm{m}^{2}$ of $\beta$-cypermethrin in water. Fabrics were then naturally dried lying flat on a polyethylene sheet for $24 \mathrm{~h}$, so that any liquid that dripped out of the fabric was reabsorbed. Control fabrics were treated only with water.

PIF samples that were $10 \times 10 \mathrm{~cm}$ underwent acetone extraction several times in an ultrasonic bath for $1 \mathrm{~h}$ each time. Acetone extracts were mixed and volume made up to $50 \mathrm{~mL}$. The concentration of $\beta$-cypermethrin was determined by gas-liquid chromatography (Shimadzu 6AM Chromatograph, Japan) using a glass column filled with Silicone DC QF-1 1.5\% on Chromosorb W (AW-DMCS) mesh 60-80 (Shimadzu, Japan) at $220{ }^{\circ} \mathrm{C}$ and a flame detector at $250{ }^{\circ} \mathrm{C}$, against a standard of $\beta$-cypermethrin $0.02 \%$, according to internal guidelines Chemotécnica uses for quality control.

Four different bioassays were done. The first assessed insecticidal activity for all eight of the fabrics. On each piece of treated PIF, 10 first-instar nymphs were exposed for $1,3,6$, or 10 min at room temperature $\left(25^{\circ} \mathrm{C}\right)$, confined inside a glass ring with an inner diameter of $4.8 \mathrm{~cm}$. The nymphs were then transferred to a disposable clean flask and kept at $25^{\circ} \mathrm{C}$. Mortality was assessed $24 \mathrm{~h}$ posttreatment. Median lethal time $\left(\mathrm{LT}_{50}\right)$ values were calculated with a computer software program specially designed in our laboratory based on probit analysis using the Litchfield and Wilcoxon method (22). Fabrics treated only with water were used as control assays.

To evaluate fabrics that had been used in the field, 10 first-instar nymphs were exposed for $3,6,9$, or $12 \mathrm{~min}$ to PIF samples from treated dwellings and were then transferred to a clean flask. Mortality was assessed $24 \mathrm{~h}$ after exposure. $\mathrm{LT}_{50}$ was calculated with a computer software program specially designed in our laboratory based on probit analysis using the Litchfield and Wilcoxon method (22).

Residual activity was measured with PIFs that had been held in indoor environmental conditions $\left(25^{\circ} \mathrm{C}\right)$; their insecticidal activity was determined at $7,15,30,90,120,240$, and 365 days after impregnation. 
In an assessment of repellency, fabrics impregnated with $\beta$-cypermethrin were compared with ones impregnated with deltamethrin and cypermethrin, at a sublethal dose of $8.3 \mathrm{mg} / \mathrm{m}^{2}$ as a target dosage for all three pyrethroids. Groups of 10 first-instar nymphs were held in a transparent plastic container $(15 \mathrm{~cm} \times 30 \mathrm{~cm})$ for $30 \mathrm{~min}$ to become acclimated before placing two small dark shelters simultaneously inside the plastic container. One of the shelters contained the fabric impregnated with pyrethroid. The other shelter, the control, contained the same fabric but without pyrethroid. The dark shelters were small plastic vessels $\left(100 \mathrm{~cm}^{3}\right)$, with openings in the lower part of each of them. Both shelters were put in place at the same time, separated by not more than a few centimeters. After $60 \mathrm{~min}$, there was no mortality of insects at the assayed dosage. The number of insects inside the two dark shelters was counted and compared. This simple methodology suitably quantified the nymphs' hiding movements, which mimicked the natural behavior of triatomines searching for dark shelter. Repellency was defined as a negative taxis, with a lower ratio meaning a higher repellency effect (23). A simple calculation was used for repellency calculations. Each value was the mean of five replicates $\pm \operatorname{SD}(n=10)$. Significance was determined by the nonparametric Mann-Whitney test $(P<0.005)$.

\section{Field trials}

For the field trials, two of the fabrics, $100 \%$ wool and the rayon-cotton combination, were impregnated in the laboratory by immersing pieces that were $60 \mathrm{~m} \times 1.5 \mathrm{~m}$ for $60 \mathrm{~min}$ in a vessel containing $60 \mathrm{~L}$ of a mixture of $5 \%$ EC $\beta$-cypermethrin, for a target dosage of $200 \mathrm{mg}$ a.i. $/ \mathrm{m}^{2}$. The fabric was then wound on a wooden pole and placed in a draining rack with a grate below it to collect the runoff. After the excess liquid had dripped off, the fabric was left to dry for $24 \mathrm{~h}$ on lines outdoors but not in direct sunlight. After that, the fabric was folded and stored in polyethylene bags until it was to be used in the field.

The rayon-polyester fabric was impregnated in the field ("in situ"), rather than in the laboratory. Fabric pieces of $5 \mathrm{~m} \times 1.5 \mathrm{~m}$, folded to $0.31 \mathrm{~m}$ $\times 0.37 \mathrm{~m}$, were immersed for $60 \mathrm{~min}$ inside a polyethylene bag that was $0.95 \mathrm{~m} \times 0.50 \mathrm{~m}$ and $30 \mu$ thick and that contained $4 \mathrm{~L}$ of a solution of $\beta$-cypermethrin (EC 5\%) in water, for a final concentration of $1 \mathrm{~g}$ a.i./ $/ \mathrm{m}^{2}$. After being soaking in the closed plastic bag, the fabric was wrung out, allowing the excess insecticide to drip back into the plastic bag. The folded fabric was placed flat on a polyethylene sheet for drying for at least $24 \mathrm{~h}$, with any liquid dripping out of the fabric being reabsorbed during this process. Impregnated fabrics were stored in polyethylene bags until they were to be used inside the dwellings.

In the houses, samples of the impregnated fabrics were nailed up under the roof or attached to camp beds. Using small tacks the PIFs were nailed to the horizontal wooden tie beams that supported the straw and mud roof of each home. The tacks held the fabric in place just below the straw where the adult bugs and large nymphs hid, covering the whole roof area and hindering the triatomines' movement. In the case of the camp beds the impregnated fabric was nailed to wooden pieces supporting the mattress, so as to impede the movement of small nymphs that hid in holes in those wood pieces.

Every two months a health official visited the dwellings and looked for live insects or signs of triatomine bugs, such as eggs, exuvias, or fecal deposits on the walls and in the María Sensor Box, as described by Wisnivesky-Colli (24). Dwellings in the same area and with similar characteristics, but without PIFs installed, were used as controls. Both the PIF and control dwellings had been infested before the treatment program began.

Preliminary field trials using PIFs with a target dosage of $200 \mathrm{mg}$ a.i. $/ \mathrm{m}^{2}$ were started in 1993 in different localities of the province of Santiago del Estero, Argentina. This program was done in cooperation with the Dr. M. Fatala Chaben Institute for the Diagnosis and Treatment of Chagas' Disease of Argentina and the National Program for Chagas' Disease Control of the Ministry of Public Health of Argentina.

A first field experiment was performed with two fabrics that had been impregnated in the laboratory, with $100 \%$ wool fabric in 11 dwellings and with the rayon-cotton combination fabric in 5 dwellings. The PIFs remained in place for 1 year. Five infested houses were used as controls.

In 30 dwellings a second experimental cycle was carried out with rayonpolyester fabrics impregnated in field conditions, at a target dosage of $1 \mathrm{~g}$ a.i. $/ \mathrm{m}^{2}$. The PIFs were left in place for more than a year. Five infested houses were used as controls.

\section{RESULTS}

The characteristics of all the tested fabrics are shown in Table 1. For dilute EC solutions, the uptake of emulsified pyrethroid is considered similar to the uptake of water (5). Thus, water absorbency was used to calculate the amount of EC ( $\mathrm{mL}$ ) needed to provide the required target pyrethroid dosage for a given area of fabric.

The chemical composition of the fibers was also established, in order to standardize the different type of fabrics, as well as the mesh, by measuring the number of fibers $/ \mathrm{cm}^{2}$ by $\mathrm{mi}^{-}$ croscopy (Table 1).

Table 1 also shows which combinations of pyrethroid and fabric material were the most effective, as indicated by the $\mathrm{LT}_{50}$ data for first-instar nymphs. Four materials gave values below 3 min: wool, rayon-polyester, rayon-cotton, and tulle. Analysis of the impregnated fabrics, given by the target dosage, shows that the amount of insecticide absorbed depends on the type of fabric used. Such fabrics as cotton give high target dosage values but, as can be seen in the mortality data, the insecticide is not bioavailable. Other fabrics, such as tulle, have low target dosages but give high initial mortality $\left(\mathrm{LT}_{50}=2.1 \mathrm{~min}\right)$. 
TABLE 1. Fabric characteristics and insecticidal activity, Argentina, 1993-1995

\begin{tabular}{|c|c|c|c|c|c|}
\hline Fabric & $\begin{array}{l}\text { Chemical } \\
\text { composition }\end{array}$ & Fibers $/ \mathrm{cm}^{2}$ & $\begin{array}{c}\text { Water } \\
\text { absorption } \\
\left(\mathrm{mL} / \mathrm{m}^{2}\right)\end{array}$ & $\begin{array}{l}\text { Target } \\
\text { dosage } \\
\left(\mathrm{mg} / \mathrm{m}^{2}\right)\end{array}$ & $\begin{array}{l}\text { Median lethal } \\
\text { time (min)a,b }\end{array}$ \\
\hline Wool & $100 \%$ wool & 800 & $230 \pm 10$ & $170 \pm 10$ & $0.6(0.3-1.3)$ \\
\hline Cotton & $100 \%$ cotton & 1100 & $290 \pm 10$ & $305 \pm 21$ & $16.5(7.7-35.0)$ \\
\hline Rayon-polyester & $\begin{array}{l}51.2 \% \text { rayon }+ \\
48.8 \% \text { polyester }\end{array}$ & 1100 & $240 \pm 10$ & $260 \pm 10$ & $2.8(2.1-3.5)$ \\
\hline Cotton-polyester & $\begin{array}{l}58 \% \text { cotton }+ \\
42 \% \text { polyester }\end{array}$ & 1200 & $230 \pm 10$ & $235 \pm 10$ & $3.0(2.3-3.9)$ \\
\hline Rayon-cotton & $\begin{array}{c}43 \% \text { rayon + } \\
57 \% \text { cotton }\end{array}$ & 400 & $360 \pm 20$ & $93 \pm 18$ & $1.7(1.1-2.6)$ \\
\hline Tulle & $100 \%$ polyester & 200 & $32 \pm 5$ & $23 \pm 18$ & $2.1(1.6-2.8)$ \\
\hline Voile & $100 \%$ polyamide & 1600 & $64 \pm 5$ & $25 \pm 18$ & $8.6(5.7-13.1)$ \\
\hline Taffeta & $\begin{array}{c}100 \% \text { cellulose } \\
\text { acetate }\end{array}$ & 600 & $48 \pm 5$ & $26 \pm 4$ & $9.8(5.4-17.2)$ \\
\hline
\end{tabular}

All values are the mean of at least two independent determinations.

${ }^{a}$ Controls of fabrics without insecticide showed $0 \%$ mortality in all cases.

${ }^{\text {b } M e d i a n}$ values with $95 \%$ confidence intervals.

TABLE 2. Residual efficacy of $\beta$-cypermethrin-impregnated fabrics, Argentina, 1996

\begin{tabular}{lccccccc}
\hline & \multicolumn{7}{c}{ Mortality (\%) $)^{\mathrm{a}, \mathrm{b}}$} \\
\cline { 2 - 8 } \multicolumn{1}{c}{ Fabric } & 7 days & 15 days & 30 days & 90 days & 120 days & 240 days & 365 days \\
\hline Wool & 100 & 100 & 100 & 100 & 100 & 100 & 90 \\
Rayon-cotton & 100 & 100 & 100 & 100 & 100 & 80 & 50 \\
Rayon-polyester & 100 & 100 & 100 & 90 & 80 & 50 & - \\
Cotton-polyester & 70 & 0 & - & - & - & - & - \\
Tulle & 0 & - & - & - & - & - & - \\
Taffeta & 0 & - & - & - & - & - & - \\
Voile & 0 & - & - & - & - & - & - \\
\hline
\end{tabular}

a The values are the mean of at least two independent determinations.

${ }^{b}$ Controls of fabrics without insecticide did not show any mortality in any cases.

Table 2 shows the residual efficacy data. Only wool, rayon-cotton, and rayon-polyester produced high mortality (> 80\%) for more than 3 months. Because its initial mortality was so low, the $100 \%$ cotton fabric was not investigated for residual activity.

Table 3 shows that for the three pyrethroids tested on fabrics, $\beta$-cypermethrin had the lowest repellency ratio and thus the greatest repellency effect.

Preliminary field trials that were performed using wool fabrics in 11 dwellings and rayon-cotton fabrics in 5 dwellings showed no infestation 1 year after PIF installation (Table 4). In the second cycle, performed with rayon-polyester fabric in 21 dwellings, there was no triatomine infestation almost 1 year after the PIFs were installed (Table 4). Another 9 dwellings in which rayon-polyester fabrics were impregnated in field conditions were also negative after a similar length of time. Meanwhile, the 5 infested houses used as controls for each trial did not show any change in infestation (Table 4). All the evaluations of infestation were done by trained personnel using the María sensor boxes. Bioassays performed in the laboratory with fabric samples taken from the dwellings 1 year after installation showed that those PIFs remained active in comparison with PIFs kept in the laboratory at $25^{\circ} \mathrm{C}$ for the same period of time (Table 5).

\section{DISCUSSION}

This study is the first to evaluate the effectiveness of fabrics impregnated with $\beta$-cypermethrin to control the Chagas' disease vector in Argentina by placing the PIFs under the roof as a sanitary ceiling and under bed mattresses. The immersion method was chosen as the most convenient method of impregnating fabrics based on previous experience $(25,26)$. The emulsified concentrate was preferred for impregnation instead of a flowable or a wetting powder because the EC provides better adhesion to the fiber and does not leave a powdery residue.

In earlier studies, our laboratory evaluation of $\beta$-cypermethrin against $T$. infestans nymphs and adult insects showed a performance similar to that of deltamethrin (15). The vector control and the cost-effectiveness ratio were very promising for this new pyrethroid. Taking into account preliminary assays that gave $100 \%$ mortality in all stages of $T$. infestans (unpublished results), the target dosage of $200 \mathrm{mg}$ a.i. $/ \mathrm{m}^{2}$ was chosen for the impregnation of fabrics for laboratory bioassays.

Evaluation of the different types of fabrics indicates that only wool, rayoncotton, and rayon-polyester showed both good triatomicidal activity and long residuality. Previous studies showed that cotton is a very porous and absorbent material, thus it could pick up more insecticide than synthetic fibers. However, a substantial portion of the insecticide would not be bioavailable, and the water absorbed produces longer drying times after impregnation (27). In contrast, pyrethroids have almost the same polarity as such synthetic fabrics as polyester, so diffusion into the fabric would occur during impregnation with subsequent slow release (28). Consequently, the bioavailability of the insecticide is more dependent on the composition of the fabric, such as 
TABLE 3. Repellency effect of fabrics impregnated with various pyrethroids toward 1st-instar nymphs of Triatoma infestans, Argentina, 1996

\begin{tabular}{lcc}
\hline Compound & $\begin{array}{c}\text { \% of sheltered insects } \\
\text { after } 60 \text { min }^{\mathrm{a}}\end{array}$ & Repellency ratio \\
\hline $\begin{array}{l}\text { B-cypermethrin } \\
\text { Deltamethrin }\end{array}$ & $28.0 \pm 4.5^{\mathrm{b}}$ & 0.36 \\
Cypermethrin & $54.0 \pm 11.4^{\mathrm{b}}$ & 0.65 \\
Control & $52.0 \pm 16.4^{\mathrm{b}}$ & 0.70 \\
& $88.8 \pm 14.8$ & 1 \\
\hline
\end{tabular}

a,b Each value is the mean of five replicates $\pm \operatorname{SD}(n=10)$. Superscript letter ${ }^{b}$ indicates significant difference with respect to the control groups $(P<0.005)$. Significance was determined by the Mann-Whitney nonparametric test.

TABLE 4. Field trials with $\beta$-cypermethrin-impregnated fabrics for Triatoma infestans control, Argentina, 1993-1997

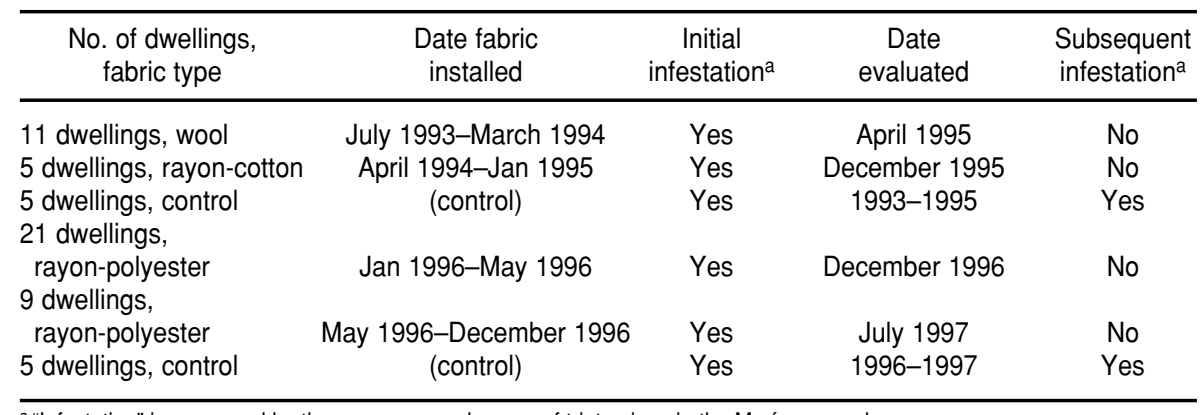

a "Infestation" is measured by the presence or absence of triatomines in the María sensor boxes.

TABLE 5. Insecticidal activity of PIFs taken from field trials 1 year after impregnation, Argentina, 1995-1997

\begin{tabular}{clc}
\hline Dwelling & Characteristic of fabric & $\begin{array}{c}\text { Median lethal time } \\
(\mathrm{min})\end{array}$ \\
\hline 1 & a) clean fabric & $4.2(2.9-6.0)$ \\
& b) smudged fabric & $8.9(6.9-11.5)$ \\
3 & clean fabric & $21.0(15.7-28.1)$ \\
& PIF painted by residents & $>40$ \\
Control & a) external painted side & $34.9(25.6-47.5)$ \\
& b) internal unpainted side & $4.8(3.4-6.7)$ \\
\hline a & Impregnated fabric held in &
\end{tabular}

${ }^{a}$ Median values with $95 \%$ confidence intervals.

rayon-polyester or cotton, than on the target dosage. Therefore, taking into account their long residuality and local availability, wool, rayon-cotton, and rayon-polyester fabrics were chosen for the field trials.

Our interest in testing the repellency of PIFs in Chagas' disease vectors using the simple methodology we devised was based on two concerns. First, there was a need to know the actual performance, in both laboratory and field conditions, of this new approach. This approach could be called "nonprofessional," in that it is carried out with community participation and the supervision of a health care agent, in contrast to conventional spraying done by an experienced, professional team. Second, new methods of pest management may come from the changes in the bugs' behavior due to the repellency action that was found. Compared with deltamethrin and cypermethrin, the two other pyrethroids currently used in national campaigns in Argentina, $\beta$-cypermethrin showed twice as much repellency effect in the tested fabrics.

In field trials, wool, rayon-cotton, and rayon-polyester fabrics impregnated with $\beta$-cypermethrin, either used as a sanitary ceiling under the roof or placed under the mattress, showed very good efficacy and good residuality for Chagas' disease vector control. The dwelling residents also accepted the PIFs well and were, in fact, delighted to receive them.

To ensure adequate residuality in field conditions, a dose of $1 \mathrm{~g}$ a.i. $/ \mathrm{m}^{2}$ was chosen, a concentration that was five times the one used in the laboratory.

In the field all three fabrics tested performed well and had equivalent costs; the major expense was the insecticide, not the fabric.

Installing the PIFs did not present difficulties and had added benefits beside their triatomicidal activity. The fabric nailed to the tie beams completely concealed the roof area and also kept dust from the roofing materials from falling on the residents. And given that the insecticide was only targeted to the ceiling, it was likely that human exposure was very low.

There has previously been a failure to develop safe, effective, longlasting prophylactic agents to reduce Chagas' disease. This study has shown that an effective method to decrease Chagas' disease is by integrating the use of impregnated fabrics within large-scale primary health care programs. This vector control method proved to be appropriate in terms of both acceptability and achievability in rural areas of Argentina.

Finally, it can be concluded that pyrethroid-impregnated fabrics are very effective in reducing exposure to 
bites from triatomines and other nuisance insects. Whether this reduction has an effect on Chagas' disease prevalence rates and morbidity will depend on a variety of local factors. Among these are seasonal fluctuations in the level of endemicity of Chagas' disease, and the immune status of the population. In areas with low levels of Chagas' disease transmission, PIFs appeared to be effective in reducing parasite rates, particularly as indoor treatments that are part of a surveillance program. In highly endemic areas, PIFs should be supplemented by other
Chagas' disease vector control methods. This is especially true for peridomiciliated triatomines, which could be eradicated by conventional insecticide spraying.

This PIF approach represents a real possibility as a complementary insecticidal tool in vector control programs.

Acknowledgments. We express thanks for the cooperation that Elsa Segura and her staff at the Dr. M. Fatala Chaben Institute for the Diagnosis and Treatment of Chagas' Disease of

\section{REFERENCES}

1. Schreck CE, Smith N, Weidhaas D, Posey K, Smith D. Repellents vs. toxicants as clothing treatments for protection from mosquitoes and other biting flies. J Econ Entomol 1978;71 (6):919-922.

2. TDR News 1995;47:9.

3. World Health Organization. The use of impregnated bednets and other materials for vector-borne disease control. Geneva: WHO; 1989. (WHO Document WHO/VBC/89.981).

4. Li ZZ, Zhang MC, Wus YG, Zhong BL, Lin GY, Huang H. Trial of deltamethrin impregnated bednets for control of malaria transmitted by Anopheles sinensis and An. anthropaphagus. Am J Trop Med Hyg 1989;40(4): 356-359.

5. Hossain MI, Curtis CE, Heekin JP. Assays of permethrin impregnated fabrics and bioassays with mosquitoes. Bull Ent Res 1989;79(2): 299-308.

6. Miller J. Relative efficacy of three pyrethroid insecticides for treating mosquito nets. Pest Outlook 1994;5(4):23-25.

7. Lindsay SW, Gibson M. Bednets revisited, an old idea, a new angle. Parasitol Today 1988;4: 237-240.

8. Curtis CF, Lines JD, Carnevale $\mathrm{P}$, Robert V, Boudin C, Halna J-M, et al. Impregnated bed nets and curtains against malaria mosquitoes. In: Curtis CF, ed. Appropriate technology in vector control. Boca Raton, Florida: CRC Press; 1990. p. 5-46.

9. Rozendaal JA. Self protection and vector control with insecticide treated mosquito nets. Geneva: World Health Organization; 1989. (WHO Document WHO/VBC/89.965).

10. MacCormack CP. Appropriate vector control in primary health care. In: Curtis CF, ed. Appropriate technology in vector control. Boca Raton, Florida: CRC Press; 1990. p. 221-228.

11. Ronderos CR, Schnack JA. Ecological aspects of Triatominae in Argentina. In: Brenner RR,
Stoka A, eds. Chagas' disease vectors. Vol I: Taxonomic, ecological, and epidemiological aspects. Boca Raton, Florida: CRC Press; 1987. p. 85-98.

12. Petana WB. Educación para el control de la enfermedad de Chagas. Bol Oficina Sanit Panam 1976;81:50-56.

13. Paulone I, Chuit R, Perez A, Wisnivesky-Colli $\mathrm{C}$, Segura E. Field research on an epidemiological surveillance alternative of Chagas' disease transmission: the primary health care (PHC) strategy in rural areas. Rev Arg Microbiol 1988;20(suppl):103-105.

14. Zerba EN. Chemical control of Chagas' disease vectors. Biomed Environ Sci 1989;2(1): 24-29.

15. Zerba E, Wallace G, Picollo MI, Casabé N, Licastro SA, Wood E, Hurvitz A, Andres A. Evaluación de la $\beta$-cipermetrina para el control de Triatoma infestans. Rev Panam Salud Publica 1997;1(2):133-137.

16. Worthing C, Hance R. Pesticide manual. 9th ed. Farnham, Surrey, United Kingdom: British Crop Protection Council; 1991. p. 212.

17. Pap L, Bajomil D, Szekely Y. Pyrethroids, an overview. Internat Pest Control 1996;38(1): 15-19.

18. World Health Organization. The WHO recommended classification of pesticides and hazard and guidelines to classification. 1988-1989. Geneva: WHO. (WHO Publication $\mathrm{WHO} / \mathrm{VBC} / 99.953)$

19. Picollo MI, Wood E, Zerba E, Licastro SA, Ruveda M. Métodos de laboratorio para medir la toxicidad de insecticidas en Triatoma infestans. Acta Bioq Clínica Latinoam 1976;10: 67-70.

20. Picollo MI, Zerba E. Un nuevo método sensible para evaluar biologicamente la acción residual de formulados insecticidas. In: Triatoma infestans. Proc. VIII Arg Cong of Toxicol, 1992, p. 82. the Ministry of Health of Argentina provided through the María Program in Santiago del Estero, Argentina. We are very grateful to Claudio Alderete, a primary health care assistant with the Ministry of Health of Argentina in Termas de Río Hondo, Santiago del Estero, Argentina, for monitoring the field trials. This investigation received financial support from the United $\mathrm{Na}$ tions Development Program/World Bank/World Health Organization Special Programme for Research and Training in Tropical Diseases and from Chemotécnica S.A. (Argentina).
21. International Standards Organization. ISO 1833. Geneva: ISO; 1975.

22. Litchfield JT, Wilcoxon FJ. A simplified method of evaluating dose-effect experiments. J Exp Ther 1949;96:99-100.

23. Dethier VG, Barton Brown L, Smith CN. The designation of chemicals in terms of responses they elicit from insects. J Econ Entomol 1960;53:134-136.

24. Wisnivesky-Colli C, Paulone I, Chuit R, Perez A, Segura E. A new method for the detection of reinfested households during surveillance activities of control programmes of Chagas' disease. Rev Argent Microbiol 1988;20(1 Suppl): 96-102.

25. Schreck CE, Self LS. Bednets kill mosquitoes. World Health Forum 1985;6:342-346.

26. Schreck CE, Self LS. Treating mosquito nets for better protection from bites and mosquitoborne disease. Geneva: World Health Organization; 1985. (WHO Publication WHO/VBC/ 85.914).

27. Rozendaal JA. Impregnated mosquito nets and curtains for self-protection and vector control. Trop Diseases Bull 1989;86(7):1-41.

28. Lindsay SW, Hossain MI, Bennett S, Curtis CE. Preliminary studies on the insecticidal activity and wash fastness of twelve pyrethroid treatments impregnated into bednetting assayed against mosquitoes. Pest Sci 1991;32: 397-411.

Manuscript received on 31 January 1998. Revised version accepted for publication on 11 January 1999. 
RESUMEN Triatoma infestans es el principal vector de la enfermedad de Chagas en Argentina. La experiencia adquirida en las campañas nacionales de este país ha demostrado que la fumigación de los domicilios para controlar los triatómidos es cara y difícil. Un método de control alternativo que podría ser un complemento práctico y barato de las medidas de control convencionales sería el empleo de telas impregnadas de piretroides. Los insectos que intentaran penetrar la tela o caminaran sobre ella en busca de comida serían intoxicados por la exposición al piretroide absorbido.

En este estudio se utilizó un concentrado emulsionado del piretroide $\beta$-cipermetrina [ $\alpha$-ciano-3-fenoxibencil-3-(2,2-diclorovinil)-2,2-dimetil-ciclopropanocarboxilato] para impregnar diferentes telas y después se investigó su eficacia y persistencia para matar a Triatoma infestans.

Los bioensayos de laboratorio revelaron que, con una dosis de $\beta$-cipermetrina de $0,2 \mathrm{~g} / \mathrm{m}^{2}$, el efecto insecticida era más duradero en la lana que en el algodón o el rayón. Ocho meses después de la impregnación, se registró una eficacia residual de $100 \%$ en la lana, de $80 \%$ en las telas de rayón y algodón y de $50 \%$ en las de rayón y poliéster. Además, las telas impregnadas de $\beta$-cipermetrina presentaron mayor efecto repelente que las impregnadas de deltametrina o cipermetrina.

En los estudios de campo, después de ser impregnadas in situ con una dosis de $\beta$-cipermetrina de $1 \mathrm{~g} / \mathrm{m}^{2}$ y secadas, las telas fueron colocadas en el interior de las casas, debajo de los colchones o clavadas al techo. Estos estudios de campo demostraron que el método era muy eficaz para mantener los domicilios sin triatómidos durante al menos un año y que tenía un alto grado de aceptación por parte de los moradores.

\section{Note of Appreciation}

The Pan American Health Organization would like to thank the Lyford Cay Foundation for its very generous contribution of 100 copies of the recently issued Health in the Americas publication, for distribution in the Bahamas to community libraries, high schools, hospitals, clinics, and Ministry of Health units. The gift will make the encyclopedic information, analysis, and statistics in the quadrennial, two-volume book available to students, medical professionals, and the general public.

The Lyford Cay Foundation is a nonprofit foundation that was established in 1969. The foundation makes charitable grants for scholarships for Bahamian students and for other recreational, educational, health, and cultural needs in the Bahamas, especially those of children and young adults. 